\title{
Incidence and Management of Cotton Whitefly Bemisia tabaci Under High Density Planting System (HDPS)
}

\author{
N. Rajasekhar $^{1 *}$, N.V.V.S. Durga Prasad ${ }^{2}$, D.V. Sai Ram Kumar ${ }^{1}$ and M. Adinarayana ${ }^{3}$ \\ ${ }^{1}$ Department of Entomology, Agricultural College, Bapatla, ANGRAU \\ 2 (Entomology), RARS, Lam, Guntur, ANGRAU; \\ ${ }^{3}$ RARS, Lam, Guntur, ANGRAU \\ *Corresponding author
}

\section{A B S T R A C T}

\section{Keywords}

Whitefly, Normal spacing and HDPS

Article Info

Accepted:

16 February 2018

Available Online:

10 March 2018
The study on "Incidence and Management of Cotton whitefly, Bemisia tabaci Under High Density Planting System (HDPS)" was conducted at RARS, Lam, Guntur during kharif, 2016-17 to observe the incidence of whitefly under HDPS and to determine the efficacy of flonicamid 50\% WG, diafenthiuron $50 \% \mathrm{WP}$, acephate $75 \%$ SP, monocrotophos $36 \%$ SL, fipronil $5 \%$ SC, buprofezin $25 \%$ SC and imidacloprid $17.8 \%$ SL under HDPS. There is no significant difference was observed in the incidence of whiteflies in both normal and HDPS. Among the tested insecticides diafenthiuron 50\% WP @ 1.25g.L $\mathrm{L}^{-1}$ was found effective in reducing whitefly population in normal spacing as well as high density planting system. Followed by flonicamid 50\% WG @ 0.3g.L $\mathrm{L}^{-1}$ and acephate 75\% SP @ $1.5 \mathrm{~g} . \mathrm{L}^{-1}$ was found effective against whitefly.

\section{Introduction}

Among sucking cotton pest complex, whitefly Bemisa tabaci (Hemiptera: Aleyrodidae) is very important and dangerous cotton pest and cotton leaf curl virus (CLCuV) vector. It has the potential of destabilizing cotton production. Its attack on cotton starts from the early phase up to maturity (Tayyab et al., 2005). It damages the cotton plant by sucking cell sap ensuring 50\% decrease in boll yield (Ashfaq et al., 2010). Whitefly feeds on cotton leaves and causes damage to the cotton crop, by sucking the cell sap from under surface of leaves, it secrets the honey dews, as a result sooty mold grows on secretions of honey dew which reduces the photosynthetic area of leaves and transmitting the viral diseases to cotton crop (Khan \& Ahmad, 2005) by transmitting vector of leaf curl virus disease (CLCuV) (Ahmad, 1999) which is great threat to our cotton-based economy (Amjad et al., 2009). It transmits more than hundred plant viruses belonging to Begomovirus (Geminiviridae), Grinivirus (Closteroviridae) and Carlavirus (Potyviridae). Among different control measures against sucking pests, the use of chemical pesticides for the control of insect pests is quick and rapid one, hence it is an effective component for integrated pest management (IPM) of crops. Hence keeping 
the above points in view the present study was conducted on "Incidence and management of cotton whitefly Bemisia tabaci under high density planting system (HDPS)"

\section{Materials and Methods}

Field trial was conducted during kharif, 201617, at Regional Agricultural Research Station, Lam, Guntur. The experiment on incidence of whitefly in cotton under HDPS was laid out in two bulk plots $\left(500 \mathrm{~m}^{2}\right)$ under normal $(15873$ plants per $\mathrm{ha}^{-1}$ ) and high density planting system (133333 plants per ha ${ }^{-1}$ ) and the variety used was NDLH-1938, a Gossypium hirsutum variety. The population of whitefly was recorded per three leaves i.e., each one from top, middle and bottom canopies of the plant from 20 plants from each bulk plot at 15 days interval starting from three weeks after sowing by random selection.

Another field trail was conducted on management of the whitefly was laid in split plot design with two main plots (to compare efficacy of insecticides in both spacings) i.e., one with normal spacing $(105 \times 60 \mathrm{~cm})$ another with HDPS $(75 \times 10 \mathrm{~cm})$. Each main plot caries eight sub plots (insecticidal treatments) which replicated thrice with the plot size of $6 \times 5 \mathrm{~m}$. The insecticidal treatments include flonicamid 50\% $\quad$ WG $\quad @ \quad 0.3 \quad$ g. $\mathrm{L}^{-1}$, diafenthiuron 50\% WP @ 1.25 g. $\mathrm{L}^{-1}$, acephate 75\% SP @ 1.5 g.L $\mathrm{L}^{-1}$, monocrotophos 36\% SL@1.6 ml.L - $^{-1}$, fipronil 5\%SC @2 ml. $\mathrm{L}^{-1}$, buprofezin 25\% SC @ $2 \mathrm{ml} . \mathrm{L}^{-1}$, imidacloprid 17.8\% SL @ 0.4 ml. $\mathrm{L}^{-1}$ and control. All treatments were applied at 15 days interval, of which the first spray was initiated when whitefly population crossed the ETL.The data on whitefly population was recorded on three leaves per plant i.e., top, middle and bottom portion of the plant on five randomly selected and tagged plants per treatment. The data was collected at one day before spraying and $3^{\text {rd }}$ and $7^{\text {th }}$ day after spray.

The percentage reduction of the pest population over untreated control for each treatment was calculated by using Abbott's formula as given by Fleming and Ratnakaran (1985).

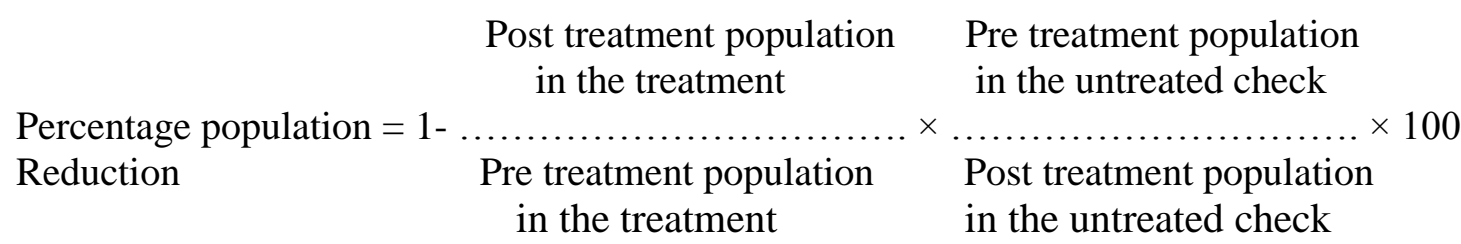

\section{Results and Discussion}

\section{Incidence of whitefly under high density planting system}

The incidence of whitefly population ranged from 0.55 to 3.80 whitefly's per three leaves in normal spacing (Table 1) and 0.95 to 3.80 in HDPS during crop growth period. The whitefly population in HDPS, showed significant difference from normal spacing only at 45 DAS. Thereafter there is no significant difference was found in both the spacings throughout the cropping period (60, $75,90,105,120,135$ and 150 DAS).

Throughout the crop growth period whitefly population did not cross the ETL (30 whitefly's per three leaves) in normal as well as HDPS, it is may be due to the domination of other sucking pests such as jassids, thrips and aphids.

Present findings are not in agreement with the findings of Patel et al., (2015) who found that maximum population of whitefly was 
recorded (3.97/ leaf) from those $B t$ cotton plots raised at plant spacing of $120 \times 45 \mathrm{~cm}$, narrow spacing. The whitefly population decreased significantly i.e. 1.16/ leaf with $150 \times 60 \mathrm{~cm}$, wider plant spacing.

\section{Cumulative efficacy of three sprays against cotton whitefly (B. tabaci)}

A total of three sprays were given and pooled data was analysed and presented hereunder.

Cumulative data of three sprays before application of insecticides against whitefly population ranged from 2.33 to $6.53 / 3$ leaves in normal and 4.07 to 7.00 whitefly $/ 3$ leaves in HDPS. The effect of insecticidal treatments against whitefly population varied significantly at all the post-treatment counts of normal and HDPS (Table 2).

In normal spacing, at $3 \mathrm{DAT}$, the mean value data revealed that diafenthiuron 50\% WP and flonicamid 50\% WG were proved highly effective insecticides over control with maximum reduction of 94.07 and $92.33 \%$ respectively which were statistically at par with one another, followed by acephate $75 \%$ SP and buprofezin $25 \%$ SC which were also found to be effective with reduction of 87.56 and 82.85 per cent and statistically differ with one another. Least reduction of whitefly population was observed in fipronil $(62.05 \%)$ treated plot which statistically differ with other treatments.

At 3 DAT, among the treatments, significantly the highest per cent reduction of whitefly population over control was observed in plots treated with diafenthiuron $50 \%$ WP (96.39\%) and it was statistically differ with other treatments, followed by flonicamid 50\% WG and acephate $75 \%$ SP were found to be effective by reducing whitefly population to the extent of 93.65 and $92.45 \%$ and statistically on par with one another respectively in HDPS. Lowest reduction of pest population was observed in fipronil 5\% SC (72.84\%) treated plot and statistically differ with one another.

Table.1 Incidence of whitefly at two different spacings in cotton

\begin{tabular}{|c|c|c|c|}
\hline \multirow[t]{2}{*}{ DAS } & \multicolumn{2}{|c|}{ Whitefly } & \multirow[b]{2}{*}{ t-test } \\
\hline & Normal & HDPS & \\
\hline 45 & $\begin{array}{c}1.50 \\
(1.22)\end{array}$ & $\begin{array}{c}3.80 \\
(1.94)\end{array}$ & Sig \\
\hline 60 & $\begin{array}{c}3.80 \\
(1.94)\end{array}$ & $\begin{array}{c}5.05 \\
(2.24)\end{array}$ & NS \\
\hline 75 & $\begin{array}{c}1.20 \\
(1.09)\end{array}$ & $\begin{array}{c}1.80 \\
(1.34)\end{array}$ & NS \\
\hline 90 & $\begin{array}{c}1.20 \\
(1.09)\end{array}$ & $\begin{array}{c}1.40 \\
(1.18)\end{array}$ & NS \\
\hline 105 & $\begin{array}{c}1.80 \\
(1.34)\end{array}$ & $\begin{array}{c}1.10 \\
(1.04)\end{array}$ & NS \\
\hline 120 & $\begin{array}{c}1.10 \\
(1.04)\end{array}$ & $\begin{array}{c}1.30 \\
(1.14)\end{array}$ & NS \\
\hline 135 & $\begin{array}{c}0.95 \\
(0.97)\end{array}$ & $\begin{array}{c}0.95 \\
(0.97)\end{array}$ & NS \\
\hline 150 & $\begin{array}{c}0.55 \\
(0.74)\end{array}$ & $\begin{array}{c}0.95 \\
(0.97)\end{array}$ & NS \\
\hline Mean \pm SE & $1.51 \pm 0.35$ & $2.04 \pm 0.54$ & \\
\hline Df & & & \\
\hline t-cal.value & & & \\
\hline
\end{tabular}


Table.2 Cumulative efficacy of three sprays against whitefly under HDPS

\begin{tabular}{|c|c|c|c|c|c|c|c|c|c|c|c|c|c|c|c|c|c|c|c|c|}
\hline \multirow{3}{*}{$\begin{array}{c}\text { Insecticidal } \\
\text { treatment }\end{array}$} & \multicolumn{4}{|c|}{ Pre-treatment count } & \multicolumn{8}{|c|}{ Population no/3leaves/plant* } & \multicolumn{8}{|c|}{ Per cent population reduction over control $* *$} \\
\hline & & & & & \multicolumn{4}{|c|}{3 DAT } & \multicolumn{4}{|c|}{$7 \mathrm{DAT}$} & \multicolumn{4}{|c|}{3 DAT } & \multicolumn{4}{|c|}{$7 \mathrm{DAT}$} \\
\hline & M1 & \multicolumn{3}{|c|}{ M2 } & \multicolumn{2}{|c|}{ M1 } & \multicolumn{2}{|c|}{ M2 } & \multicolumn{4}{|c|}{ M2 } & \multicolumn{2}{|c|}{ M1 } & \multicolumn{2}{|c|}{ M2 } & \multicolumn{2}{|c|}{ M1 } & \multicolumn{2}{|c|}{$\mathrm{M} 2$} \\
\hline $\begin{array}{l}\text { Flonicamid } \\
50 \% \text { WG }\end{array}$ & $\begin{array}{c}3.33 \\
(1.82)\end{array}$ & \multicolumn{3}{|c|}{$\begin{array}{l}6.27 \\
(2.50)\end{array}$} & \multicolumn{2}{|c|}{$\begin{array}{c}0.69 \\
(0.83)\end{array}$} & \multicolumn{2}{|c|}{$\begin{array}{c}0.80 \\
(0.89)\end{array}$} & \multicolumn{2}{|c|}{$\begin{array}{c}0.67 \\
(0.82)\end{array}$} & \multicolumn{2}{|c|}{$\begin{array}{c}0.58 \\
(0.76)\end{array}$} & \multicolumn{2}{|c|}{$\begin{array}{c}92.33 \\
(73.83)^{\mathrm{a}}\end{array}$} & \multicolumn{2}{|c|}{$\begin{array}{c}93.65 \\
(75.37)^{b}\end{array}$} & \multicolumn{2}{|c|}{$\begin{array}{c}93.16 \\
(74.81)^{b}\end{array}$} & \multicolumn{2}{|c|}{$\begin{array}{c}95.11 \\
(77.19)^{\mathrm{b}}\end{array}$} \\
\hline $\begin{array}{c}\text { Diafenthiuron } \\
50 \% \text { WP }\end{array}$ & $\begin{array}{c}2.33 \\
(1.52)\end{array}$ & \multicolumn{3}{|c|}{$\begin{array}{l}5.33 \\
(2.31)\end{array}$} & \multicolumn{2}{|c|}{$\begin{array}{c}1.00 \\
(1.00)\end{array}$} & \multicolumn{2}{|c|}{$\begin{array}{c}0.47 \\
(0.68)\end{array}$} & \multicolumn{2}{|c|}{$\begin{array}{c}0.40 \\
(0.63)\end{array}$} & \multicolumn{2}{|c|}{$\begin{array}{c}0.27 \\
(0.51)\end{array}$} & \multicolumn{2}{|c|}{$\begin{array}{c}94.07 \\
(75.87)^{\mathrm{a}}\end{array}$} & $\begin{array}{r}96 . \\
(79.0\end{array}$ & & $\begin{array}{r}95 \\
(78\end{array}$ & & $\begin{array}{r}97 . \\
(81 .\end{array}$ & \\
\hline $\begin{array}{c}\text { Acephate } 75 \% \\
\text { SP }\end{array}$ & $\begin{array}{c}3.67 \\
(1.91)\end{array}$ & & $\begin{array}{r}4.0 \\
(2.0 \\
\end{array}$ & & $\begin{array}{l}1.1 \\
(1 .(\end{array}$ & & $\begin{array}{l}0 . \\
(0 .\end{array}$ & & $\begin{array}{r}0.8 \\
(0.9\end{array}$ & & $\begin{array}{r}0.8 \\
(0.8\end{array}$ & & $\begin{array}{r}87 \\
(69 \\
\end{array}$ & $\begin{array}{l}56 \\
31)^{b}\end{array}$ & $\begin{array}{r}92 . \\
(74.0\end{array}$ & & $\begin{array}{r}91 \\
(72\end{array}$ & & $\begin{array}{r}93 . \\
(74 .\end{array}$ & \\
\hline $\begin{array}{c}\text { Monocrotopho } \\
\text { s 36\% SL }\end{array}$ & $\begin{array}{c}6.53 \\
(2.55)\end{array}$ & & $\begin{array}{r}6.8 \\
(2.6\end{array}$ & & $\begin{array}{l}2.1 \\
(1.2\end{array}$ & & $\begin{array}{l}1 . \\
(1 .\end{array}$ & & $\begin{array}{r}1.4 \\
(1.1\end{array}$ & & $\begin{array}{r}1.4 \\
(1.1\end{array}$ & & $\begin{array}{r}77 \\
(61 \\
\end{array}$ & $\begin{array}{l}20 \\
15)^{\mathrm{d}}\end{array}$ & $\begin{array}{r}89 . \\
(70.6\end{array}$ & & $\begin{array}{r}85 \\
(67 .\end{array}$ & & $\begin{array}{r}87 . \\
(69 .\end{array}$ & $3)^{\mathrm{e}}$ \\
\hline $\begin{array}{c}\text { Fipronil 5\% } \\
\text { SC }\end{array}$ & $\begin{array}{c}6.40 \\
(2.52)\end{array}$ & & $\begin{array}{r}4.6 \\
(2.1 \\
\end{array}$ & & $\begin{array}{l}3.3 \\
(1.8\end{array}$ & & $\begin{array}{l}3 . \\
(1 .\end{array}$ & & $\begin{array}{r}3.2 \\
(1.8\end{array}$ & & $\begin{array}{r}3.6 \\
(1.9\end{array}$ & & $\begin{array}{r}62 \\
(51\end{array}$ & $\begin{array}{l}05 \\
95)^{\mathrm{e}}\end{array}$ & $\begin{array}{r}72 . \\
(58.5\end{array}$ & & $\begin{array}{r}60 \\
(50\end{array}$ & & $\begin{array}{r}66 . \\
(54 .\end{array}$ & \\
\hline $\begin{array}{c}\text { Buprofezin } \\
25 \% \text { SC }\end{array}$ & $\begin{array}{c}3.07 \\
(1.75)\end{array}$ & & $\begin{array}{r}6.0 \\
(2.4\end{array}$ & & $\begin{array}{l}1.2 \\
(1.1\end{array}$ & & $\begin{array}{l}1 . \\
(1 .\end{array}$ & & $\begin{array}{r}1.0 \\
(1.0\end{array}$ & & $\begin{array}{r}1.0 \\
(1.0\end{array}$ & & $\begin{array}{r}82 \\
(65\end{array}$ & $\begin{array}{l}85 \\
50)^{\mathrm{c}}\end{array}$ & $\begin{array}{r}91 . \\
(73.3\end{array}$ & & $\begin{array}{r}89 . \\
(71.0\end{array}$ & $6)^{\mathrm{cd}}$ & $\begin{array}{r}91 . \\
(72 .\end{array}$ & \\
\hline $\begin{array}{c}\text { Imidacloprid } \\
17.8 \% \text { SL }\end{array}$ & $\begin{array}{c}3.27 \\
(1.80)\end{array}$ & & $\begin{array}{r}5.0 \\
(2.2\end{array}$ & & $\begin{array}{l}1.8 \\
(1.3\end{array}$ & & $\begin{array}{l}1 . \\
(1 .\end{array}$ & & $\begin{array}{r}1.1 \\
(1.0\end{array}$ & & $\begin{array}{r}1.1 \\
(1.0\end{array}$ & & $\begin{array}{r}81 \\
(64 .\end{array}$ & $\begin{array}{l}50 \\
0)^{\mathrm{cd}}\end{array}$ & $\begin{array}{r}89 . \\
(71 .\end{array}$ & & $\begin{array}{r}87 . \\
(69 .\end{array}$ & $4)^{d}$ & $\begin{array}{r}89 . \\
(71 .\end{array}$ & $\begin{array}{l}2 \\
6)^{d}\end{array}$ \\
\hline $\begin{array}{c}\text { Untreated } \\
\text { Control }\end{array}$ & $\begin{array}{c}4.53 \\
(2.12)\end{array}$ & & $\begin{array}{r}7.0 \\
(2.6\end{array}$ & & $\begin{array}{r}9.2 \\
(3.0\end{array}$ & & $\begin{array}{l}12 \\
(3 .\end{array}$ & & $\begin{array}{r}9.0 \\
(3.0\end{array}$ & & $\begin{array}{l}11.1 \\
(3.3\end{array}$ & & & & - & & - & & - & \\
\hline & $\begin{array}{c}\mathrm{F} \\
\text { test }\end{array}$ & $\begin{array}{l}\mathrm{SE} \\
\mathrm{M}\end{array}$ & $\mathrm{CD}$ & $\mathrm{CV}$ & $\begin{array}{c}\mathrm{F} \\
\text { test }\end{array}$ & SEM & $\mathrm{CD}$ & $\mathrm{CV}$ & $\begin{array}{c}\mathrm{F} \\
\text { test }\end{array}$ & SEM & $\mathrm{CD}$ & $\mathrm{CV}$ & $\begin{array}{c}\mathrm{F} \\
\text { test }\end{array}$ & SEM & $\mathrm{CD}$ & $\mathrm{CV}$ & $\begin{array}{c}\mathrm{F} \\
\text { test }\end{array}$ & SEM & $\mathrm{CD}$ & $\mathrm{CV}$ \\
\hline Main plot & NS & 0.71 & NS & 15.01 & NS & 0.06 & NS & 62.42 & NS & 0.06 & NS & 21.24 & NS & 6.75 & NS & 28.19 & NS & 3.73 & NS & 15.47 \\
\hline Sub plot & NS & 0.32 & NS & 9.68 & Sig & 1.16 & 0.29 & 19.89 & Sig & 0.98 & 0.14 & 7.57 & Sig & 6.45 & 3.48 & 4.06 & Sig & 6.74 & 1.84 & 2.11 \\
\hline Interaction & NS & 0.28 & NS & & NS & 0.13 & NS & & NS & 0.08 & NS & & NS & 1.91 & NS & & NS & 0.97 & NS & \\
\hline & $\begin{array}{l}\text { ares in } \\
\text { yures }\end{array}$ & taic &  & $\begin{array}{l}\text { are sc } \\
\text { are }\end{array}$ & are $r$ & cansfo & . & $\begin{array}{l}\text { value } \\
\text { ues. }\end{array}$ & & $\begin{array}{l}\text { Sig : } \\
N S: \text { I }\end{array}$ & sis & $\begin{array}{l}\text { at. } \\
\text { icant }\end{array}$ & $\begin{array}{l}\mathrm{M} \\
\mathrm{M}\end{array}$ & $\begin{array}{l}\text { Norm } \\
\text { High }\end{array}$ & $\begin{array}{l}\text { paci } \\
\text { isity }\end{array}$ & $\begin{array}{l}\text { (105 } \\
\text { antin }\end{array}$ & $\begin{array}{l}60 \mathrm{c} \\
(75 \mathrm{x}\end{array}$ & $\mathrm{cm})$ & & \\
\hline
\end{tabular}

In HDPS, at 7 DAT the highest reduction of the pest was recorded to be 97.72 per cent in the treatment were diafenthiuron 50\% WP was sprayed and statistically superior than the all other treatments, followed by flonicamid 50\% WG and acephate 75\% SP with 95.11 and 93.23 per cent reduction of whitefly and statistically differ with one another. The lowest reduction of the pest was observed in fipronil 5\% SC (66.68\%) treated plot and statistically differ with other treatments. Similar trend of results was found with the normal spacing also at 7 DAT.

This results are in agreement with findings of Kalyan et al., (2017) who reported that highest reduction in population of whiteflies with mean of 66.28, 72.01, 78.13 and 68.86, $74.33,80.14$ per cent was recorded in difenthiuron 50 WP @ $300 \mathrm{~g}$ a.i. $\mathrm{ha}^{-1}$ at $3^{\text {rd }}$, $5^{\text {th }}$ and $7^{\text {th }}$ days after first spray during 2014 and 2015, respectively and it was statistically at par with flonicamid 50 WP@ $100 \mathrm{~g}$ a.i. ha ${ }^{-1}$ and fipronil 5 EC @ 100 g.ha ${ }^{-1}$. Present findings are in agreement only with the case of diafenthiuron 50\% WP and flonicamid $50 \%$ WG treatments in normal spacing and HDPS both at $3 \& 7$ DAT but fipronil 5\% SC which was proved effective was not found promising against whitefly in the present investigation.

Present findings also confirm with the findings of Razaq et al., (2005) who found that minimum whiteflies (5.39/ leaf) were observed in plots treated with diafenthiuron, acetamiprid (5.85/ leaf) and imidacloprid (6.03/leaf) at 24 hours after application of insecticides during 2002 and also to the findings of Afzal et al., (2014) who found that imidacloprid and diafenthiuron gave maximum mortality during first spray $(89.52$ and $85.50 \%$ ) and second spray (91.67 and $87.51 \%$ ) after $72 \mathrm{~h}$ of application. Present findings are in agreement with diafenthiuron only but imidacloprid proved to be least effective. 
Present experimentation confirms with the findings of Vichiter and Ramesh (2009) who found that the diafenthiuron (Polo $50 \mathrm{WP}$ ) at $400 \mathrm{~g}$ a.i. ha ${ }^{-1}$ was highly effective and significantly superior to the conventional insecticide in controlling whitefly infestation on cotton. Saradha and Nachiappan (2003) reported that diafenthiuron at $800 \mathrm{~g}$ a.i. ha $^{-1}$ reduced the population of whitefly to the maximum, followed by diafenthiuron at $600 \mathrm{~g}$ and $400 \mathrm{~g}$ a.i. ha ${ }^{-1}$ on brinjal.

Present findings are not in conformity with the findings of Sathyan et al., (2016) who found that Fipronil $5 \mathrm{SC}$ and diafenthiuron 50 WP $(0.45 / 3$ leaves $)$ were equally better than untreated check (1.25/3 leaves); they reduced the incidence of whitefly by 68 and 64 per cent compared to untreated check. The results from the present experimentation are in conformity regarding diafenthiuron 50\% WP only but fipronil 5\% SC which was proved effective was not found promising against whitefly population in the present study. The efficacy of insecticides in controlling whitefly population in normal and HDPS was similar as there is no difference in population reduction over control.

\section{References}

Afzal, M., Babar, M.H., Ibrar-UL-Haqand Iqbal, Z. 2014.Bio-Efficacy of New Insecticides Against Whitefly, Bemisia tabaci (Genn.) on Cotton, Bt-121. Pakistan Journal of Nutrition :13 (6): 340-343, 2014.

Ahmad, Z., 1999. 'Pest Problems of Cotton, A Regional Perspective', Proceedings of ICAC-CCRI, Regional Consultation Insecticides Resistance Management in Cotton, June 28-July 1 , Multan, Pakistan, pp. 5-20.

Amjad, M., M. H .Bashir, M. Afzal and M. A. Khan, 2009. Efficacy of Some Insecticides Against (Bemisa tabaci.
Genn.) Infesting Cotton under Field Conditions. Pakistan journal of and Life Social Sciences, 7(2): 140-143.

Ashfaq, M., M. Noor-ul-Aen, K. Zia, A. Nasreen and M. Hassan, 2010. The correlation of abiotic factors and physico-morphic characteristics of (Bacillus thuringiensis) Bt transgenic cotton with Bemisa tabaci (Homoptera: Aleyrodidae) and jassid, Amrasca devastans (Homoptera: Jassidae) populations. African Journal of Agricultural Research, 5 (22): 31023107.

Fleming $\mathrm{R}$ and Ratnakaran A. 1985. Evaluating single treatment data using Abbot's formula with modification. Journal of Economic Entomology 78:1179.

Kalyan, R.K., Saini, D.P., Meena, B.M., Abhishek, P., Naruka, P., Verma, S and Joshi, S. 2017. Evaluation of new molecules against jassids and white flies of Bt cotton. Journal of Entomology and Zoology Studies; 5(3): 236-240.

Khan, J. A. \& J. Ahmad, 2005. Diagnosis, monitoring and transmission characteristics of cotton leaf curl virus. Current Sciences, 88: 1803-1809.

Patel, C.K., Bharpoda, T.M., Zala, M.B and Shah, K.D. 2015. Impact of plant spacing and nitrogenous fertilizer on incidence of sucking pests in $B t$ cotton. International journal of plant protection, volume 8 (1): 34-40

Razaq, M., Anjum, S., Jalal Arif, $M$ and Mushtaq, A.S. 2005. Evaluation of neonicotinoids and conventional insecticides against jassid, Amrasca devastans (Dist.) and cotton whitefly, Bemisia tabaci (Genn.) on cotton. Pakistan Entomologist. 27(1): 75-80.

Saradha, C and Nachiappan, R.M. 2003.Evaluation of diafenthiuron 50\% WP (Polo) against whitefly, Bemisia tabaci Genn. (Aleyrodidae: Homoptera) 
brinjal (Solanam melongena). Pestology. 27(1): 12-14.

Sathyan, T., Murugesan, N., Elanchezhyan, K., Arockia Stephen Raj J and Ravi, G. 2016. Efficacy of Synthetic Insecticides against sucking insect pests in cotton, Gossypium hirsutum L. International Journal of Entomology Research. 1: 1621

Tayyib, M., A. Sohail, Shazia, F. Murtaza, and F.F. Jamil. 2005. Efficacy of some
New-hemistry Insecticides for controlling the Sucking insect pests and mites on cotton. Pakistan Entomologist, 27(1): 63-66.

Vichiter, S and Ramesh, C. 2009. Testing the new molecule polo 50 WP (Diafenthiuron) against cotton whitefly, Bemisia tabaci (Gen). Pestology. 33(3): 50-52.

How to cite this article:

Rajasekhar, N., N.V.V.S. Durga Prasad, D.V. Sai Ram Kumar and Adinarayana, M. 2018. Incidence and Management of Cotton Whitefly Bemisia tabaci Under High Density Planting System (HDPS). Int.J.Curr.Microbiol.App.Sci. 7(03): 2074-2079.

doi: https://doi.org/10.20546/ijcmas.2018.703.243 